\title{
Ashura beel in Dinajpur district: Limnological aspect
}

\author{
Z. Ferdoushi*, Y. Ara, T. Khatun and K. K. U. Ahmed ${ }^{1}$ \\ Department of Fisheries Management, Faculty of Fisheries, Hajee Mohammad Danesh Science and Technology \\ University, Dinajpur and ${ }^{1}$ Bangladesh Fisheries Research Institute, Shrimp Research Station, Bagerhat-9300, \\ Bangladesh, *E-mail: zannatul99bd@yahoo.com
}

\begin{abstract}
An investigation was carried out on the limnological aspects of Ashura beel at Dinajpur district in Bangladesh. Several limnological parameters were evaluated from March 2013 to October 2013 from three sampling sites namely Kajladoho, Burirdoho and Sonnasydoho. Physical, chemical and biological parameters were analyzed fortnightly both at the field level and departmental laboratory of Fisheries Management, Hajee Mohammad Danesh Science and Technology University, Dinajpur. Findings revealed that only water level in three sampling sites varied significantly. The ranges of water temperature, transparency, water level at three sampling sites were 24 to $35.50^{\circ} \mathrm{C}, 17$ to $27.50 \mathrm{~cm}$ and 0.58 to $2.44 \mathrm{~m}$, respectively. Moreover, the dissolved oxygen concentration, $\mathrm{pH}$, total alkalinity, total hardness and phosphate-phosphorus concentration were also remained within optimum ranges. Thirty four genera were recorded where phytoplankton includes 29 genera belonging to four groups such as euglenophyceae, cyanophyceae, bacillariophyceae and chlorophyceae and five genera of zooplankton in the four groups namely copepoda, rotifera, cladocera and crustacean larvae. Phytoplankton was dominated by chlorophyceae and zooplankton dominated by copepoda. The abundance of phytoplankton was positively correlated with water temperature, water level, dissolved oxygen, alkalinity, hardness, $\mathrm{pH}$, and phosphate-phosphorus. On the other hand, abundance of zooplankton negatively correlated with water temperature, transparency and water level. However, from the findings of this study suggested that the water quality parameters of the selected sites were found to be suitable for the survival of aquatic organism.
\end{abstract}

Keywords: Water quality, Phytoplankton, Zooplankton

\section{Introduction}

Bangladesh is the delta of Ganga-Brahmaputra river system, transected by rivers, beels, haors, and numerous wetlands which are part and parcel of the people living in the delta. They serve as natural habitat, breeding, feeding and spawning ground of large and small indigenous fishes of different food habits (Jha, 1989). Ashura beel having no exception from the above supports to the livelihood of many fishermen in Dinajpur district in Bangladesh. A number of threatened fishes available in the beel are rarely found in other parts of the country (Amin et al., 2009).

Though the beel harbors a great variety of fishes and other aquatic plants and animals, due to increasing practice of agriculture activities and adverse climatic condition, many lotic and lentic waterbody of Bangladesh have already lost their characteristics of basin. As a result viability of aquatic resources is seriously threatened (Chakraborty and Nur, 2009). Virtually very few fundamental researches have been carried out on the beel ecosystem. However, for any sustainable fishery, study on limnological aspects becomes a major concern for environmentalist. In addition, a well planned and systematic study is required to assess water quality of the beel in order to take an appropriate action to manage the ecosystem which will ultimately increase the total inland fish production.

During 2005, the non-government organization CARITAS had completed a project on Ashura beel focusing the co-management aspects of the local community. On the other hand, Alfasane et al. (2012) examined some physico-chemical characteristics of water of Ashura beel. Different limitations of their researches have been marked including short sampling duration, lack of limnological information etc. By considering the importance of this wetland and limitation of the previous work, the present limnological investigation was undertaken to assess the following objectives: 
- To study the physico-chemical properties of water quality of the Ashura beel

- To determine the qualitative and quantitative abundance of plankton of study beel

- To observe the interrelationship between the plankton abundance and some physico-chemical parameters of the water body

\section{Materials and Methods}

\section{Description of the Study Area}

The selected study area Ashura beel, is originated from river Karotoa. It is located at Nawabgonj and Birampur subdistrict, 70 kilometers away from the Dinajpur district (Ahmed et al., 2008). Total area is about 251.78 hectare (142.00 ha. in Nawabgonj upazilla and 109.78 ha. in Birampur upazilla) which supports as feeding, breeding and spawning ground of many large and small indigenous fishes of different food habitat (Fig. 1). Three sampling sites named Kajladoho, Burirdoho, Sonnasydoho within the Ashura beel were selected for the purpose of sample collection. Before selecting these sites several field trips and focus group discussions were done. Finally, three sampling sites were randomly selected for the study purpose.

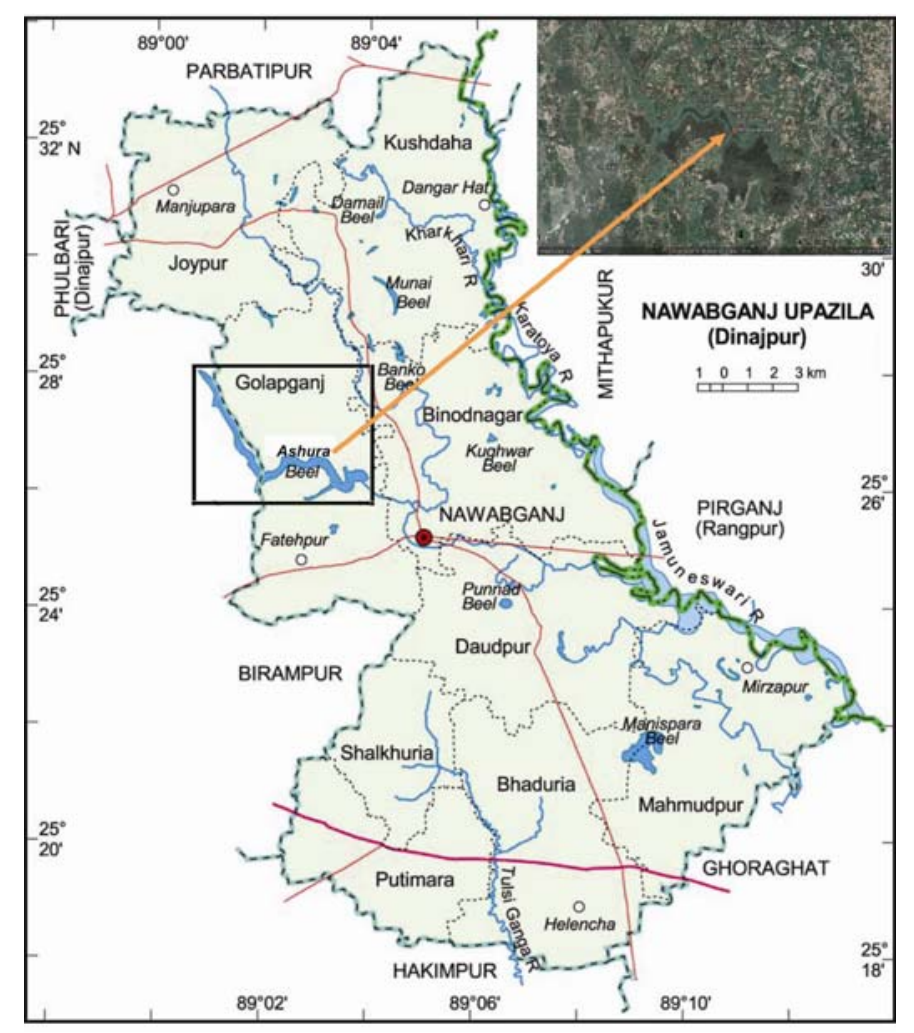

Fig. 1. Geographical position and Satellite image of Ashura beel

\section{Sampling Duration and Procedure}

Samplings were done fortnightly at three different sampling sites from March to October 2013. Water quality parameters like temperature, transparency, dissolved oxygen, $\mathrm{pH}$, hardness and phosphatephosphorus were determined in the field level. For determining other water quality parameters (chlorophyll-a, alkalinity) samples were carried into the laboratory of the department of Fisheries Management for further analysis as prescribed by APHA (1992). 


\section{Plankton Analysis}

Plankton samples were collected by filtration technique. Ten liters of water samples was collected in a plastic bucket and filtered through plankton net of $25 \mu \mathrm{m}$ mesh size. Then concentrated sample preserved in $4 \%$ formalin solution. Taxonomic identification up to genus level of plankton was carried out with the help of taxonomic keys from the text book of Barbar and Haworth (1981), Bellinger (1992), Pontin (1978), Lind and Brook (1980) under the binocular microscope. Then plankton abundance was calculated using the formula by Rahman (1992).

$\mathrm{N}=\frac{\mathrm{A} \times \mathrm{C}}{\mathrm{F} \times \mathrm{V} \times \mathrm{L}} \times 1000$

Where,

$\mathrm{N}=$ No. of plankton cells per liter

$A=$ Total no. of plankton counted

$\mathrm{C}=$ Volume of final concentrate of samples in $\mathrm{ml}$

$\mathrm{V}=$ Volume of a field in cubic millimeter

$\mathrm{F}=$ Number of the fields counted

$\mathrm{L}=$ Volume of original water in liter

\section{Statistical Analysis}

An analysis of variance (One Way ANOVA) and Tukey's test was applied to data for determining significant variation among the three sampling sites by using SPSS version 20 . Statistical significances were assessed using a probability level of $P=0.05$. An estimation of possible relation between physicochemical and plankton abundance was developed by correlation analysis and also performed with the SPSS version 20 program.

\section{Results and Discussion}

\section{Physico-chemical Parameters}

Table 1 is showing the mean values and ranges of different physico-chemical parameters of Ashura beel during the study period. Among different physical parameters only the water level varied significantly with the sampling points. Comparatively higher $(2.44 \mathrm{~m}$ ) water level was found in Burirdoho point (site 2) of Ashura beel followed by Kajladoho $(1.95 \mathrm{~m})$ and Sonnasydoho $(2.13 \mathrm{~m})$. However, almost similar values of water level were also observed by Joarder (2009) in beel Joshi of Bangladesh.

According to Rahman (1992) suitable water temperature for aquatic life should be between 26.0 to $31.0^{\circ} \mathrm{C}$. The average water temperatures of the three sampling sites were found to remain within this suitable ranges (Table 1). The maximum water temperature $\left(35.50^{\circ} \mathrm{C}\right)$ was found in the month ofJuly in site 2 , while minimum $\left(24.00^{\circ} \mathrm{C}\right)$ water temperature was found in October in site 3. Dewan (1973) also recorded the highest water temperature in July and the lowest in January.

Boyd (1982) suggested the suitable transparency for fish culture is about 15 to $40 \mathrm{~cm}$. The average values of transparency were almost found similar in all points and within suitable range. Islam and Chowdhury (2014) observed water transparency at Trimohini beel in Rajshahi District from 20 to $110 \mathrm{~cm}$. The mean values of dissolved oxygen were $6.94 \pm 0.40 \mathrm{mg} / \mathrm{L}, 6.97 \pm 0.39 \mathrm{mg} / \mathrm{L}$ and $6.96 \pm 0.44 \mathrm{mg} / \mathrm{L}$ in site 1 , site 2 and site 3 which are slightly higher $(5.57 \pm 0.16 \mathrm{mg} / \mathrm{L})$ than the value of Trimohini beel of Bangladesh (Islam and Chowdhury, 2014). The $\mathrm{pH}$ values of Ashura beel were found in alkaline ranges (Table 1). Islam and Chowdhury (2014) observed the $\mathrm{pH}$ at Trimohini beel ranges from 7.2 to 7.5 which has the conformity with the present findings. 
Table 1. Mean values ( \pm SD) and ranges of water quality parameters in different sampling sites throughout the period of study

\begin{tabular}{|c|c|c|c|c|}
\hline \multirow{2}{*}{ Parameters } & \multicolumn{3}{|c|}{ Sampling sites } & \multirow{2}{*}{$\begin{array}{c}\text { ANOVA } \\
\text { Significance }\end{array}$} \\
\hline & Site 1 & Site 2 & Site 3 & \\
\hline Water temperature $\left({ }^{\circ} \mathrm{C}\right)$ & $\begin{array}{c}28.90 \pm 2.75 \\
(24.50-33.50)\end{array}$ & $\begin{array}{c}29.35 \pm 3.14 \\
(24.00-35.50)\end{array}$ & $\begin{array}{c}29.24 \pm 3.05 \\
(24.00-34.50)\end{array}$ & NS \\
\hline Transparency (cm) & $\begin{array}{c}21.23 \pm 2.34 \\
(18.20-25.75)\end{array}$ & $\begin{array}{c}22.28 \pm 2.84 \\
(17.00-26.00)\end{array}$ & $\begin{array}{c}22.37 \pm 3.01 \\
(17.00-27.50)\end{array}$ & NS \\
\hline Water level (m) & $\begin{array}{c}1.30^{\mathrm{b}} \pm 0.41 \\
(0.58-1.95)\end{array}$ & $\begin{array}{l}1.53^{a} \pm 0.37 \\
(0.67-2.44)\end{array}$ & $\begin{array}{l}1.30^{\mathrm{b}} \pm 0.37 \\
(0.58-2.13)\end{array}$ & * \\
\hline Dissolved oxygen (mg/L) & $\begin{array}{l}6.94 \pm 0.40 \\
(5.90-7.80)\end{array}$ & $\begin{array}{l}6.97 \pm 0.39 \\
(5.90-7.83)\end{array}$ & $\begin{array}{l}6.96 \pm 0.44 \\
(6.00-7.83)\end{array}$ & NS \\
\hline $\mathrm{pH}$ & $\begin{array}{l}7.33 \pm 0.66 \\
(6.10-8.42)\end{array}$ & $\begin{array}{l}7.33 \pm 0.66 \\
(6.10-8.42)\end{array}$ & $\begin{array}{l}7.48 \pm 0.42 \\
(6.80-8.50)\end{array}$ & NS \\
\hline Alkalinity (mg/L) & $\begin{array}{l}114.25 \pm 19.38 \\
(84.00-146.00)\end{array}$ & $\begin{array}{l}112.15 \pm 19.84 \\
(80.00-142.00)\end{array}$ & $\begin{array}{l}113.19 \pm 18.99 \\
(72.00-146.00)\end{array}$ & NS \\
\hline Hardness (mg/L) & $\begin{array}{c}214.48 \pm 17.97 \\
(183.00-247.00)\end{array}$ & $\begin{array}{c}211.81 \pm 9.54 \\
(180.00-243.00)\end{array}$ & $\begin{array}{c}208.56 \pm 19.60 \\
(150.00-240.00)\end{array}$ & NS \\
\hline $\mathrm{PO}_{4}-\mathrm{P}(\mathrm{mg} / \mathrm{L})$ & $\begin{array}{l}0.75 \pm 0.09 \\
(0.60-0.88)\end{array}$ & $\begin{array}{l}0.75 \pm 0.09 \\
(0.50-0.90)\end{array}$ & $\begin{array}{l}0.75 \pm 0.08 \\
(0.60-0.90)\end{array}$ & NS \\
\hline Chlorophyll -a ( $\mu \mathrm{g} / \mathrm{L})$ & $\begin{array}{c}29.55 \pm 9.43 \\
(11.90-47.60)\end{array}$ & $\begin{array}{c}29.20 \pm 9.35 \\
(11.90-47.60)\end{array}$ & $\begin{array}{c}29.57 \pm 9.59 \\
(11.90-47.60)\end{array}$ & NS \\
\hline
\end{tabular}

NS $=$ Values are not significantly different $(P>0.05)$

* values with different superscript letters in the same row indicate a significant difference at $5 \%$ significance level based on the one-way ANOVA followed by Tukey's test

In addition, the mean $( \pm S D)$ values of total alkalinity in site 1 , site 2 and site 3 were $114.25 \pm 19.38 \mathrm{mg} / \mathrm{L}$, $112.15 \pm 19.84 \mathrm{mg} / \mathrm{L}$ and $113.19 \pm 18.99 \mathrm{mg} / \mathrm{L}$ respectively. The average range of total alkalinity level of Ashura beel was 72 to $146 \mathrm{mg} / \mathrm{L}$ which may be comparable with the range of Chanda beel (72 to 196 $\mathrm{mg} / \mathrm{L}$ ) at the Faridpur-Madaripur areas of Bangladesh (Ehshan, 1997). In addition, comparatively higher values of total hardness were recorded in three sampling sites (Table 1). The average values of phosphate-phosphorus in all sampling sites were comparatively similar and remained within the productive range (Table 1). Islam and Saha (1975) observed that the $\mathrm{PO}_{4}-\mathrm{P}$ ranged from 0.2 to $2.8 \mathrm{mg} / \mathrm{L}$ which were favorable for growth of blue green algae and diatoms. Findings of the present study were also found to be favorable for aquatic life. Measurement of chlorophyll-a is a mechanism for rating a lake's productive state. Concentration of chlorophyll-a was found higher in the month of April $(47.60 \mu \mathrm{g} / \mathrm{L})$ in site 2 followed by site 1 and 2 in the month of October $(11.90 \mu \mathrm{g} / \mathrm{L})$ which is almost similar with the finding of Maharet et al. (2000) in Manchhar lake of Pakistan.

\section{Plankton Abundance}

A total of 34 genera of plankton were identified from Ashura beel (Table 2). Table 3 is showing the mean values and ranges of different plankton groups in three sampling sites along with their level of significance. Fortnightly variations of the abundance of different plankton groups of Ashura beel are shown in Fig. 2 (a-i). Comparatively higher abundance of plankton $\left(9.88 \times 10^{3} \mathrm{cells} / \mathrm{L}\right)$ was observed in site 1 in July followed by site $2\left(2.73 \times 10^{3}\right.$ cells/L) in the month of October (Fig. $\left.2 \mathrm{e}\right)$. 
Table 2. Different groups of plankton identified in various sampling sites of Ashura beel

\begin{tabular}{ll|l}
\hline Phytoplankton & & Zooplankton \\
\hline Bacillariophyceae & Chlorophyceae & Crustacean Larvae \\
\hline Cosmarium & Ankistrodismus & Cauplius \\
Cyclotella & Asterionella & Copepoda \\
Diatoma & Chlamydomonas & Diaptomus \\
Fragillaria & Chlorella & Cladocera \\
Melosira & Closteridium & Daphnia \\
Navicula & Closterium & Rotifera \\
Nitzschia & Crucigenia & Asplanchna \\
Cyanophyceae & Microspora & Brachionus \\
Anabaena & Pediastrum & \\
Chrococcus & Scenedesmus & \\
Gloeocapsa & Spirogyra & \\
Microcystis & Staurastrum & \\
Nostoc & Synedra & \\
Oscillatoria & Volvox & \\
Spirulina & Euglenophyceae & \\
& Euglena & \\
\hline
\end{tabular}

Table 3. Mean values ( $\pm S D$ ) and range of biological parameters in different sampling points throughout the period of study

\begin{tabular}{|c|c|c|c|c|}
\hline \multirow{2}{*}{ Plankton groups } & \multicolumn{3}{|c|}{ Sampling sites } & \multirow{2}{*}{$\begin{array}{c}\text { ANOVA } \\
\text { Significance }\end{array}$} \\
\hline & $\begin{array}{c}\text { Site1 } \\
\left(\times 10^{3} \text { cells } / L\right)\end{array}$ & $\begin{array}{c}\text { Site2 } \\
\left(\times 10^{3} \text { cells } / L\right)\end{array}$ & $\begin{array}{c}\text { Site3 } \\
\left(\times 10^{3} \text { cells } / L\right)\end{array}$ & \\
\hline Euglenophyceae & $\begin{array}{c}0.49 \pm 0.15 \\
(0.31-0.80)\end{array}$ & $\begin{array}{c}0.53 \pm 0.22 \\
(0.31-1.29)\end{array}$ & $\begin{array}{c}0.50 \pm 0.18 \\
(0.31-1.17)\end{array}$ & NS \\
\hline Cyanophyceae & $\begin{array}{c}0.97 \pm 0.41 \\
(0.35-1.98)\end{array}$ & $\begin{array}{c}0.99 \pm 0.43 \\
(0.32-2.28)\end{array}$ & $\begin{array}{c}0.97 \pm 0.42 \\
(0.35-1.95)\end{array}$ & NS \\
\hline Bacillariophyceae & $\begin{array}{l}1.70 \pm 0.49 \\
(0.78-3.06)\end{array}$ & $\begin{array}{c}1.76 \pm 0.54 \\
(0.39-2.70)\end{array}$ & $\begin{array}{c}1.73 \pm 0.52 \\
(0.70-2.80)\end{array}$ & NS \\
\hline Chlorophyceae & $\begin{array}{c}2.17 \pm 0.65 \\
(0.78-3.51)\end{array}$ & $\begin{array}{l}2.08 \pm 0.65 \\
(0.64-3.36)\end{array}$ & $\begin{array}{l}1.98 \pm 0.56 \\
(0.70-3.12)\end{array}$ & NS \\
\hline Total Phytolankton & $\begin{array}{l}5.37 \pm 1.52 \\
(2.34-8.58)\end{array}$ & $\begin{array}{c}5.42 \pm 1.52 \\
(1.92-8.36)\end{array}$ & $\begin{array}{l}5.22 \pm 1.45 \\
(2.10-8.19)\end{array}$ & NS \\
\hline Copepoda & $\begin{array}{c}0.65 \pm 0.32 \\
(0.00-1.29)\end{array}$ & $\begin{array}{c}0.61 \pm 0.28 \\
(0.00-1.24)\end{array}$ & $\begin{array}{l}0.63 \pm 0.23 \\
(0.34-1.05)\end{array}$ & NS \\
\hline Crustacea & $\begin{array}{c}0.76 \pm 0.36 \\
(0.00-1.68)\end{array}$ & $\begin{array}{c}0.69 \pm 0.27 \\
(0.00-1.28)\end{array}$ & $\begin{array}{c}0.66 \pm 0.30 \\
(0.00-1.12)\end{array}$ & NS \\
\hline Total Zooplankton & $\begin{array}{l}1.40 \pm 0.62 \\
(0.39-2.94)\end{array}$ & $\begin{array}{l}1.30 \pm 0.51 \\
(0.34-2.48)\end{array}$ & $\begin{array}{c}1.31 \pm 0.47 \\
(0.37-2.10)\end{array}$ & NS \\
\hline Total Plankton & $\begin{array}{l}6.76 \pm 1.70 \\
(2.73-9.60)\end{array}$ & $\begin{array}{l}6.73 \pm 1.77 \\
(2.73-9.88)\end{array}$ & $\begin{array}{c}6.55 \pm 1.74 \\
(2.8-9.75)\end{array}$ & NS \\
\hline
\end{tabular}

NS= Values are not significantly different $(P>0.05)$

Among the four identified phytoplankton groups, chlorophyceae was found to be the most abundant and euglenophyceae was the scanty group. The abundance of total plankton ranged from $2.73 \times 10^{3} \mathrm{cells} / \mathrm{L}$ to $9.88 \times 10^{3}$ cells/L which is almost similar to the findings of Hasan, (2004). The highest density of phytoplankton was found in the month of June at site1 and lowest in the month of October at site 3. Both bacillariophyceae and cholophyceae were the dominant and most diversified groups among all sampling sites. There were seven genera under the group of bacillariophyceae and thirteen genera of chlorophyceae. Singh (1960) reported that high atmospheric or water temperature along with the bright sunshine is an important factor in the periodicity of chlorophyceae (green algae). Most common genera of 
chlorophyceae were Coelestrum, Pediastrum, Spirogyra, Staurustrum, Scenedesmus, Synedra etc. Das et al., (2011) stated that chlorophyceae was dominant group in the oxbow lake in Assam. The abundance of cyanophyceae was in the third position and the available genera were Spirulina, Anabaena and Microcystis. On the other hand, the abundances of euglenophyceae in all three sites were more or less similar throughout the study period.

Among different groups of zooplankton Copepoda, Cyclops and Diaptomas were the most common in all sampling sites. Nauplius was found higher in number than Rotifera and Cladocera in all sampling sites. An average fortnightly variation in abundance of total zooplankton is shown in Fig. 2(h). The highest average number of zooplankton was found at site 1 in March and the lowest average number at site 2 in October which is more or less similar to the finding of Chowdhury et al., (2008).

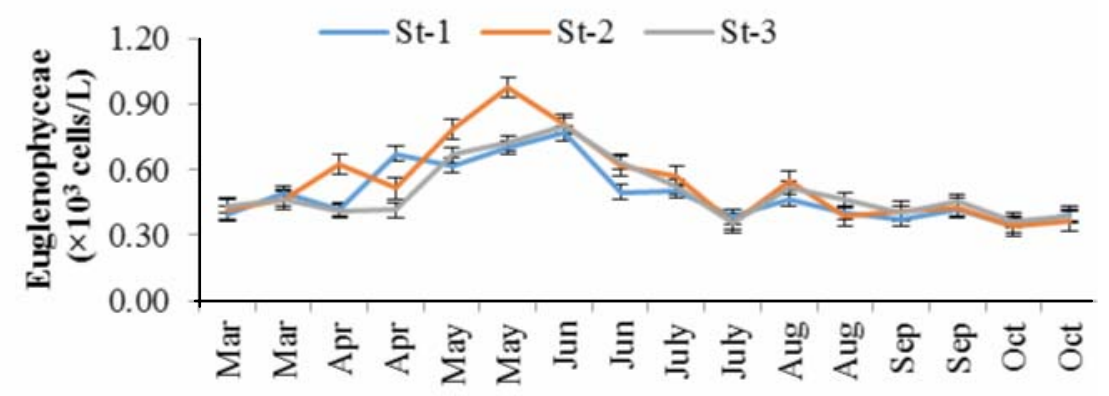

Sampling month

Fig. 2(a). Euglenophyceae

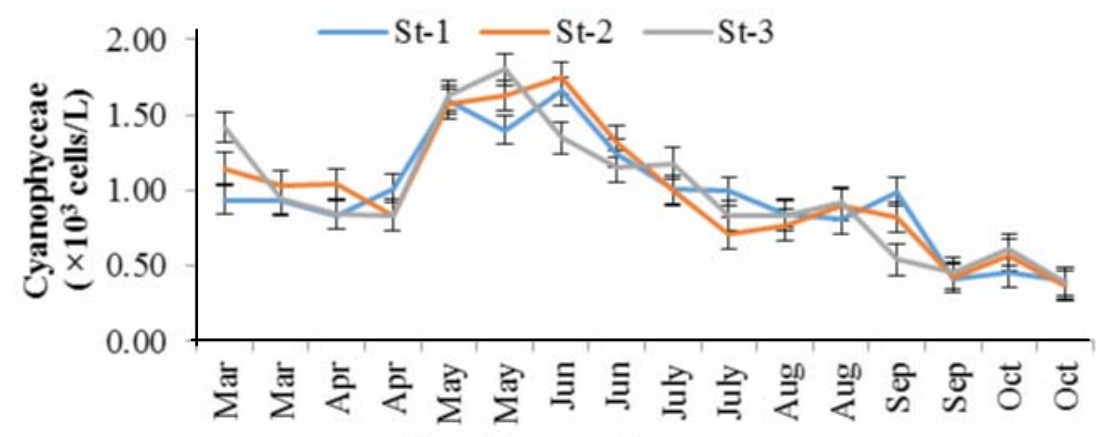

Sampling month

Fig. 2(b). Cyanophyceae

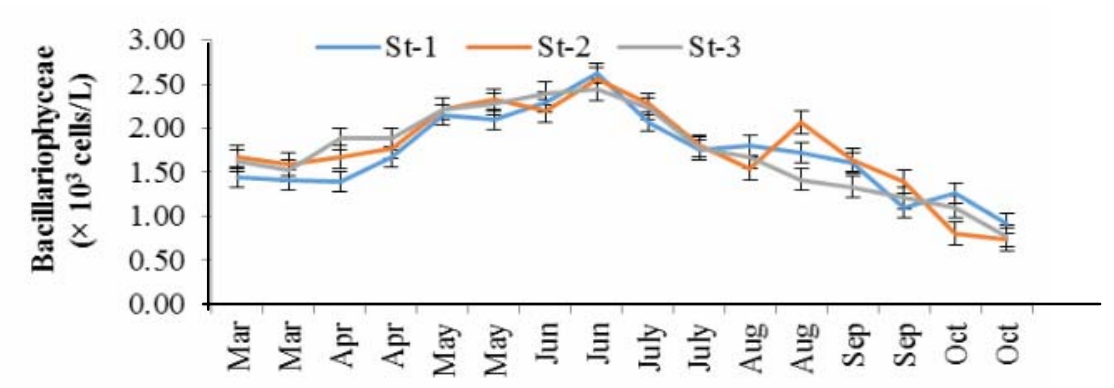

Sampling month

Fig. 2(c). Bacillariophyceae 


\section{Ferdoushi et al.}

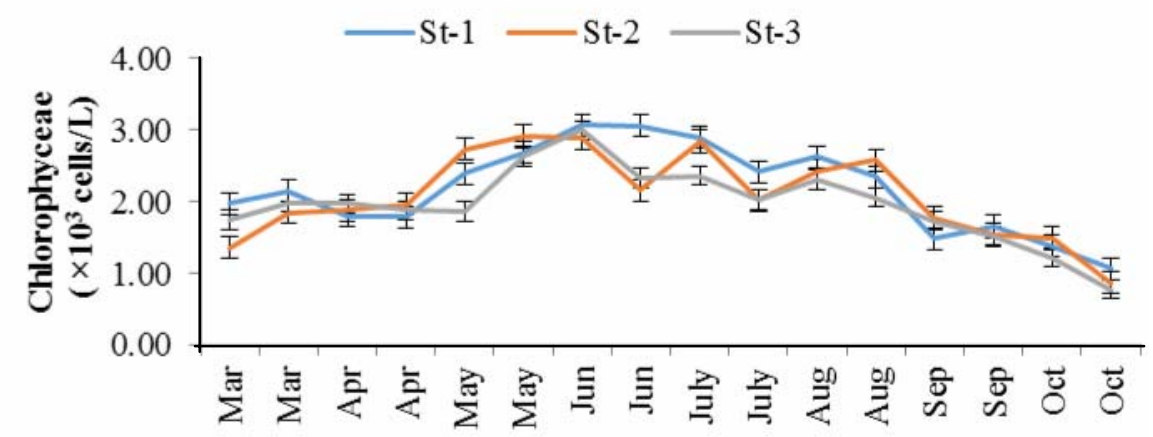

Sampling month

Fig. 2(d). Chlorophyceae

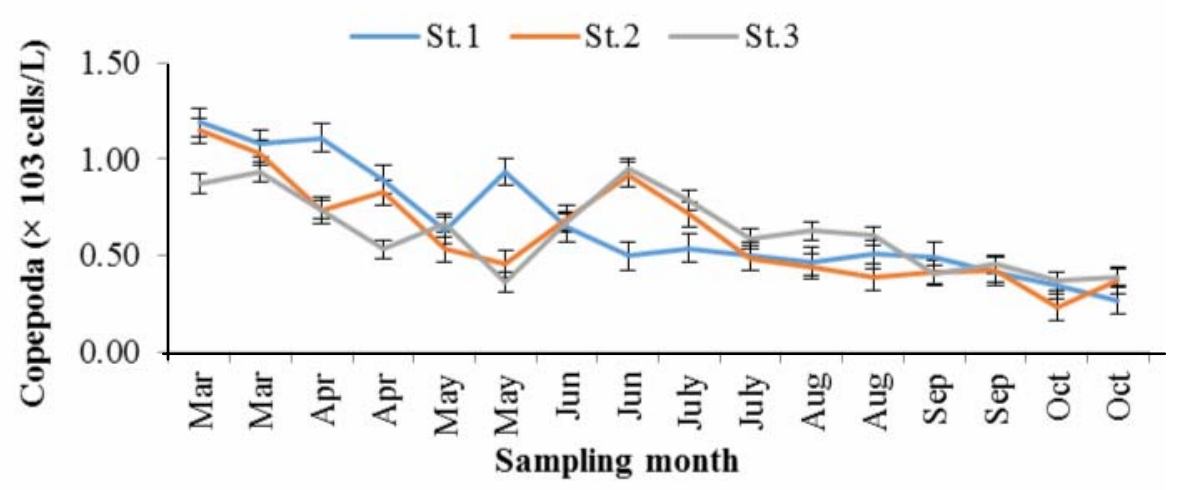

Fig. 2(e). Copepoda

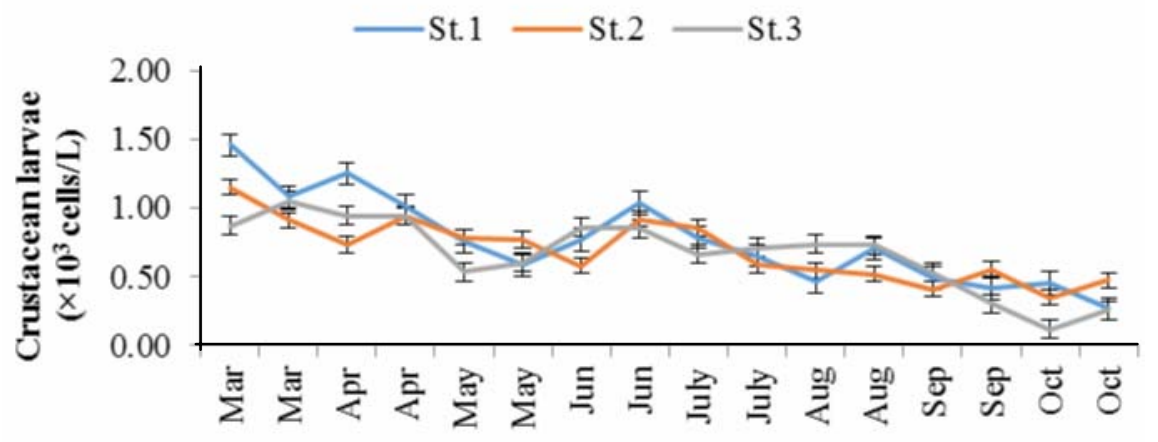

Sampling month

Fig. 2(f). Crustacea 


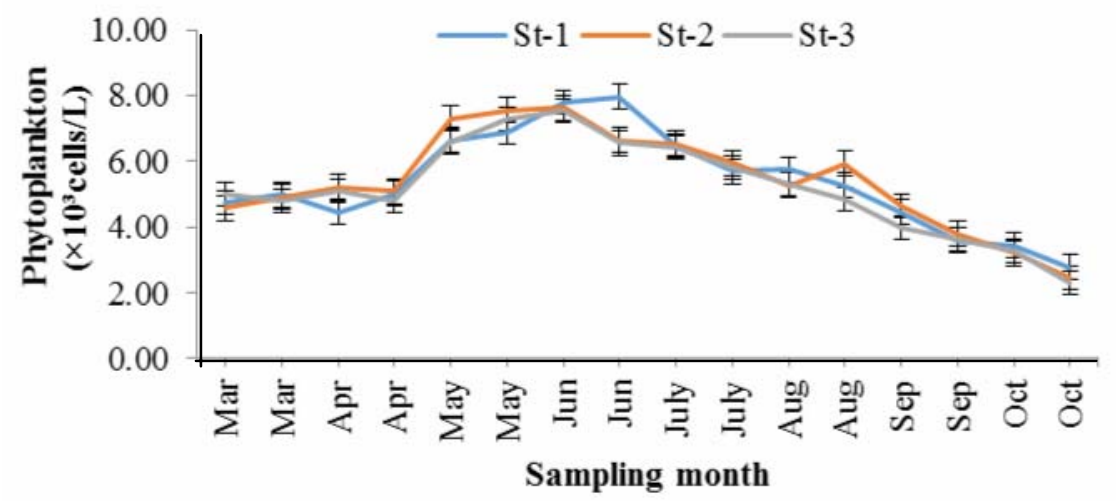

Fig. 2(g). Total phytoplankton

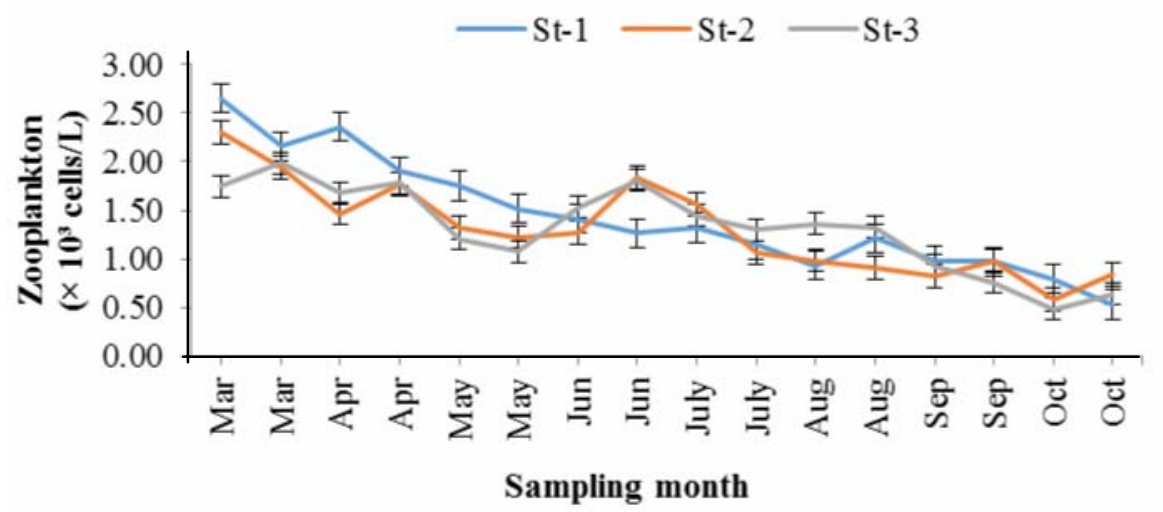

Fig. 2(h). Total Zooplankton

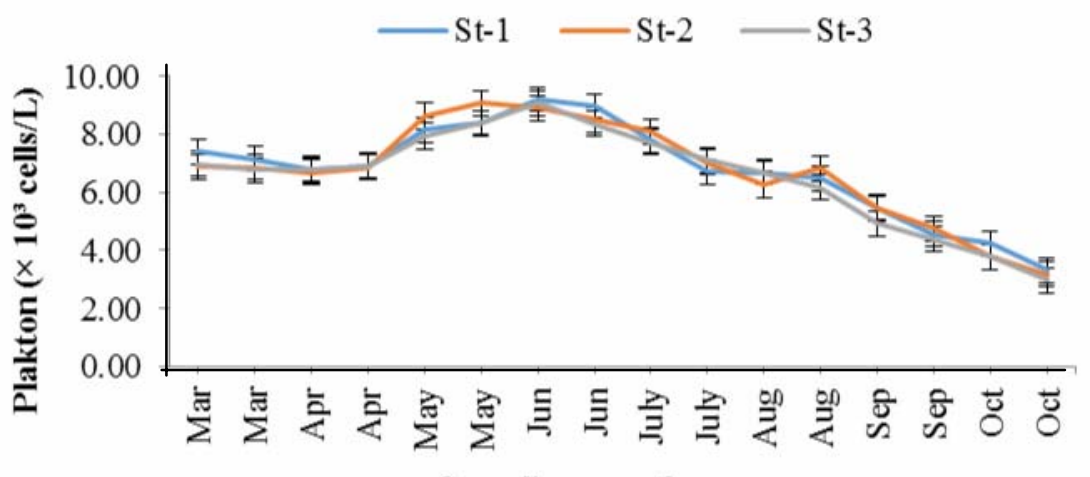

Sampling month

Fig. 2(i). Total Plankton

Fig. 2. Fortnightly variations in abundance of different groups of plankton in three sampling sites: a. Euglenophyceae, b. Cyanophyceae, c. Bacillariophyceae, d. Chlorophyceae, e. Copepoda, f. Crustacea, g. Total Phytoplankton, h. Total Zooplankton, i. Total Plankton 


\section{Effects of Some Physico-chemical Parameters on Plankton abundance of the Ashura Beel}

Effects of different water quality parameters on the abundance of plankton community were analyzed by correlation matrix. Findings from the analysis revealed that the abundance of total phytoplankton and plankton was positively correlated with water temperature, water level, dissolved oxygen, alkalinity, hardness, $\mathrm{pH}$ and phosphate-phosphorus. Whereas, abundance of total zooplankton was negatively correlated with water temperature, transparency and water level and positively correlated with other chemical parameters (Table 4). Significant positive and negative correlations between the abundance of plankton and different water quality parameters were also observed in several water bodies in Bangladesh and other parts of the world (Alam and Kabir 2003; Veerendra et al. 2012; Rajagopal et al. 2010; Patra and Azadi 1987).

Table 4. Correlation among different physico-chemical parameters and plankton groups

\begin{tabular}{lcccc}
\hline & Total Phytoplankton & Total Zooplankton & Total Plankton \\
\hline Water Temperature & $0.53^{\star *}$ & -0.04 & $0.44^{\star \star}$ \\
Transparency & $-0.72^{\star *}$ & -0.50 & $-0.66^{\star *}$ \\
Water level & $0.21^{\star}$ & $-0.51^{\star *}$ & 0.01 \\
Dissolved Oxygen & $0.28^{\star *}$ & $0.54^{\star *}$ & $0.42^{\star \star}$ \\
Alkalinity & $0.88^{\star *}$ & 0.15 & $0.81^{\star *}$ \\
Hardness & $0.85^{\star *}$ & $0.45^{\star *}$ & 0.85 \\
pH & $0.86^{\star}$ & $0.41^{\star *}$ & $0.87^{\star *}$ \\
Phosphate-phosphorus & $0.77^{\star *}$ & $0.23^{\star *}$ & $0.77^{\star \star}$ \\
\hline
\end{tabular}

\section{Conclusion}

The limnological status of Ashura beel indicates that beel is conducive to enhanced fisheries and biological production. Considering this some conservation measures must be taken by the government to protect the beel from environmental pollution.

\section{Acknowledgements}

The authors would like to thank BFRI (Bangladesh Fisheries Research Institute) for the financial support under IDRSBFRI Project and Department of Fisheries, Nowabgong, Dinajpur for kind co-operation during the research work.

\section{References}

Ahmed, N., Allison, E.H. and Muir, J.F. 2008. Using the sustainable livelihoods framework to identify constraints and opportunities to the development of freshwater prawn farming in southwest Bangladesh. Journal of the World Aquaculture Society, 39(5): 598-611.

Alam Md.T.I. and Kabir Md.A. 2003. Relationship between zooplankton abundance and physico-chemical parameters in Sundarban ecosystem during monsoon. Pakistan Journal of Biological Science. 6(8): 762-765.

Alfasane, M.A., Gani, M.A., Islam, M.S. and Khondker, M. 2012. Limnology of Lake Ashura, Dinajpur, Bangladesh. Bangladesh Journal of Botany, 41(1): 43-48.

Amin, A.K.M.R., Parvez, I., Zaman, M.B. and Amin, H.A. 2009. Study of the present status of Endangered small Indigenous species (SIS) of Fish in the Natural Waters of the North-West Part of Bangladesh. Journal of Environmental Science \& Natural Resources, 2(2): 163-168.

APHA. 1992. Standard Methods for the Examination of Water and Waste Water. $18^{\text {th }}$ ed. American Public Health Association, Washington DC, Site-1268.

Barber, H.G. and Haworth E.Y. 1981. A guide to the morphology of the diatom frustule: with a key to the British freshwater genera. Freshwater Biological Association. pp 122.

Bellinger, E.G. 1992. A key to the common Algae. The Institution of water and Environmental management. pp138.

Bellinger, E.G. 1992. A key to common algae: Freshwater, estuarine and some coastal species. London: Institution of Water and Environmental Management. 
Boyd, C.E. 1982. Water quality management for pond fish culture. Elseveir Science of Publication. CO, Amsterdam-oxford-Newyork, pp. 318.

Chakraborty, B.K. and Nur, N.N. 2009. Study on aquatic biodiversity of Medha beel in the Northern region of Bangladesh. Journal of Crop and Weed, 5(2): 4-11.

Chowdhury, M.M.R., Mondol, M.R.K. and Dewan, S. 2008. Seasonal dynamics of plankton in relation to some environmental factors in a Beel ecosystem. University Journal of Zoology, Rajshahi University, 27: 55-58.

Das, T., Pathak, K. and Devi, M.B. 2011. Phytoplankton and zooplankton communities of an Oxbow Lake in Barak Valley, Assam. Assam University Journal of Science and Technology, 7(1): 67-75.

Dewan, S. 1973. Investigations into the ecology of fishes of Mymensingh Lake. A PhD thesis submitted to the Department of Aquaculture and Management, Faculty of Fisheries, Bangladesh Agricultural University, Mymensingh. pp 191-202.

Ehshan, M.A., Hossain, M.S., Mazid, M.A., Mollah, M.F.A., Rahman, S. and Razzaque, A. 1997. Limnology of Chanda beel. Bangladesh Journal of Fisheries Research, 1(1) : 31-40.

Hasan, K.R. 2004. Studies on the Breeding performance of some resident fish species in three Beels of Brahmanbaria District (Doctoral dissertation, M. Sc. thesis, Department of Fisheries Management, Bangladesh Agricultural University, Mymensingh, pp 88).

Islam, A.K.M.N. and Saha, J.K. 1975. Limnological studies of the Ramna Lake at Dhaka. Dhaka Uni. Stud. Bull, $23: 39-46$.

Islam, M.A. and Chowdhury, A.H. 2014. Limnological status of Trimohini Beel of Rajshahi, Bangladesh. Journal of the Asiatic Society of Bangladesh, Science, 39(2): 173-182.

Jha, B.C. 1989. Classification, Management and Status of fish production in beels. Inland Fisheries Society of India. CIFRI, Barrackpore, India. pp 52-60.

Joadder, A.R. 2009. An Ecological Study on the Beel Joshi (Rajshahi District), Northern Bangladesh. Journal of Fisheries International, 4(2): 23-29.

Lind, M.E. and Brook, A.J. 1980. A key to the common desmids of the Engkishlake District. Freshwater Biological Association Scientific Publication. pp 122.

Maharet, M.A., Jafri, S.I.H., Laghari, S.M. and Khuhawar, M.Y. 2000. Studies on Water Chemistry and Fish Production of Manchar Lake, Dadu, Sindh (Pakistan).

Patra, R.W.R. and Azadi, M.A. 1987, Ecological studies on the plantonic organisms of the Halda river. Bangladesh Journal of Zoology, 15: 109-123.

Pontin, R.M. 1978. A key to the freshwater planktonic and Semi-planktonic Rotifera of the British Isles. Scientific Publication: 38. Freshwater Biological Association, Ambleside, England, UK.

Rahman, M.S. 1992. Water quality management in aquaculture. BRAC Prokashana.

Rajagopal, T., Thangamani, A., Sevarkodiyone, S.P., Sekar, M. and Archunan, G. 2010. Zooplankton diversity and physicochemical conditions in three perennial ponds of Virudhunagar district, Tamilnadu. Journal of Environmental Biology, 31: $265-272$.

Singh, H.P. 1998. Studies on primary production in Gobindsagar reservoir, Himachal Pradesh. Journal of Environmental Biology, 19(2): 167-170.

Veerendra D.N., Thirumala S., Manjunatha H. and Aravinda H.B. 2012. Zooplankton diversity and its relationship with physicochemical parameters in Mani Reservoir of Western Ghats, Region, Hosanagar Taluk, Shivamoga district, Karnataka, India, Journal of Urban and Environmental. Engeenering, 6(2): 74-77. 